\title{
Reducing risk factors in overweight adult users of the family health strategy of the Distrito Federa/1
}

\section{$\|$}

Redução de fatores de risco em adultos com

ORIGINAL | ORIGINAL excesso de peso usuários da estratégia

saúde da família no Distrito Federal

Caroline ROMEIRO2

Júlia Aparecida Devidé NOGUEIRA ${ }^{3}$

Eliane Said DUTRA²

Kênia Mara Baiocchi de CARVALHO²

A B S T R A C T

\section{Objective}

To evaluate the results of a multidisciplinary program to promote healthy habits on anthropometric and biochemical parameters on participants of the Family Health Strategy of the Distrito Federal.

\section{Methods}

The sample consisted of 279 overweight and obese adults of both sexes divided into two groups: intervention $(I G, n=198)$ and control group $(C G, n=89)$. The IG received standard Family Health Strategy care plus a multidisciplinary health promoting program that included dietary interventions and physical activity, called Set Waist Program. The control group received only standard ESF care. Data were collected at baseline and after 4 and 8 months of follow up. Body mass index, waist circumference, fasting blood glucose and lipid profile were assessed.

\section{Results}

Prevalence of obesity $(63.3 \%$ to $49.4 \%, p=0.027)$ and waist circumference $(102.2 \mathrm{~cm}$ to $94.8 \mathrm{~cm}, p<0.0001)$ were significantly reduced in IG. Total cholesterol, LDL and HDL-cholesterol were reduced in both groups.

1 Article based on the dissertation of C ROMEIRO intitled "Programa intersetorial de promoção de práticas saudáveis para adultos com excesso de peso: modelo lógico e efeito da intervenção". Universidade de Brasília; 2011.

2 Universidade de Brasília, Departamento de Nutrição, Programa de Pós-Graduação em Nutrição Humana. Campus Universitário Darcy Ribeiro, s/n., Asa Norte, 70910-900, Brasília, DF, Brasil. Correspondência para/Correspondence to: KMB CARVALHO. E-mail: <kenia@unb.br>.

3 Universidade de Brasília, Programa de Pós-Graduação em Educação Física, Faculdade de Educação Física, Brasília, DF, Brasil. Support: This study was sponsored by Portaria no $3.228 / G M$, from December $21^{\text {th }}, 2007$, Fundação de Ensino e Pesquisa em Ciências da Saúde. 
660 | C ROMEIRO et al.

\section{Conclusion}

Reductions in anthropometric measures were maximized through simple interventions that stimulated lifestyle changes. These results suggest that multidisciplinary initiatives such the Set Waist Program can be incorporated into other Family Health Strategy teams to optimize the control of obesity and health promotion. Participant compliance is an issue that deserves further investigation.

Indexing terms: Health food. Motor activity. Obesity. Overweight.

\section{R E S U M O}

\section{Objetivo}

Avaliar os resultados de um programa multidisciplinar de promoção de hábitos saudáveis sobre parâmetros antropométricos e bioquímicos em usuários da Estratégia Saúde da Família do Distrito Federal.

\section{Métodos}

A amostra foi composta por 279 adultos de ambos os sexos com sobrepeso ou obesidade, alocados em dois grupos: intervenção e. O grupo intervenção $(n=198)$ recebeu a assistência padrão da Estratégia Saúde da Família acrescida de atividades estruturadas de um programa multidisciplinar de promoção de hábitos saudáveis, o Programa Jogo de Cintura, incluindo intervenções nutricionais e de atividade física. O grupo controle $(n=89)$ recebeu exclusivamente a assistência padrão da Estratégia Saúde da Família. A coleta dos dados ocorreu no início e após 4 e 8 meses de seguimento. Foram avaliados: índice de massa corporal, circunferência abdominal; glicemia em jejum e perfil lipídico.

\section{Resultados}

No grupo intervenção foram observadas reduções significativas da prevalência de obesidade (de 63,3\% para 49,4\%; $p=0,027$ ) e na média da circunferência abdominal (de 102,2 para 94,8cm; $p<0,0001$ ). Em ambos os grupos houve reduções no colesterol total, low-density liprotein e high-density liprotein cholesterol.

\section{Conclusão}

O acompanhamento padrão da Estratégia Saúde da Família contribuiu para a redução de alguns fatores de risco em adultos com excesso de peso. Reduções nas medidas antropométricas foram maximizadas através de intervenções simples que estimulam modificações nos hábitos de vida. Esses resultados sugerem que o Programa Jogo de Cintura pode ser incorporado a outras equipes da Estratégia Saúde da Família, com o intuito de aperfeiçoar o controle da obesidade e a promoção da saúde. Questões sobre a adesão dos usuários ao programa devem ser futuramente investigadas.

Termos de indexação: Alimentos naturais. Atividade motora. Obesidade. Sobrepeso.

\section{NTRODUCTION}

Non-communicable Chronic Diseases (NCD) are a worldwide public health challenge because they reduce life expectancy and quality of life and threaten the health of millions of people, causing a negative economic and social impact on people and countries, especially those with low and middle incomes. In Brazil, recent data show that NCD are responsible for $72 \%$ of the deaths, and the repercussions are severe, especially for the low-income population?.

According to the 2011 Vigilância de Fatores de Risco e Proteção para Doenças Crônicas por Inquérito Telefônico (VIGITEL, Surveillance of Risk Factors and Protection against Chronic Diseases Telephone Survey), 49.1\% and 15.0\% of the Distrito Federal (DF, Federal District) adult population are overweight and obese, respectively. Only $24.0 \%$ of the population consumed adequate amounts of fruits and nonstarchy vegetables, and $32.8 \%$ practiced enough physical activity during their free time ${ }^{2}$. Two lowincome administrative regions of the Distrito Federa/ presented a high prevalence of NCD risk factors, namely $49.5 \%$ of the study adults were overweight or obese, $31.0 \%$ had high Waist Circumference (WC), 69\% had inadequate fruit 
intake, and $52.0 \%$ had inadequate non-starchy vegetable intake ${ }^{3}$.

Comprehensive and effective healthpromoting strategies to reduce NCD risk factors and improve health indicators are urgently needed. The success of public health interventions to reduce NCD risk factors has been attributed to surveillance and the promotion of healthy lifestyles, given that diet and level of physical activity are important modifiable factors and should be prioritized ${ }^{4,5}$.

The Distrito Federal has been integrating health-promoting initiatives in a coordinate manner since 2007, when the Plano Distrital de Promoção da Saúde (Health-Promoting Plan by District) was issued ${ }^{6}$. A multidisciplinary program called Jogo de Cintura (the literal translation is "waist movements," but figuratively, this phrase means flexible personality. It is also a play with words because more physical activity usually decreases waist circumference and improves body flexibility) to promote healthy habits and prevent NCD was planned and implemented. In its pilot phase, this program focused on the overweight adult population covered by the Family Health Strategy of the administrative region of São Sebastião (DF). São Sebastião was chosen because it has the largest Family Health Strategy coverage in Distrito Federal, which is directly related to the implementation of the associated interventions in the Distrito Federal, and because its Human Development Index (HDI) is lower than Distrito Federal mean HDI. It is a poor community challenged with social, economic, and structural hardships? .

The objective of the present study was to assess the impact of the program Jogo de Cintura on the anthropometric and biochemical parameters of overweight adult users of the Family Health Strategy of São Sebastião (DF).

\section{METHODS}

This interventional, quasi-experimental study included 279 overweight or obese adults
(Body Mass Index; $\mathrm{BMI} \geq 25 \mathrm{Kg} / \mathrm{m}^{2}$ ) and/or adults with high WC $(\geq 94 \mathrm{~cm}$ for males and $\geq 80$ for females) followed by six Family Health Strategy teams of the administrative region of São Sebastião (DF). The sample was divided into two groups, an Intervention Group (IG) and a control group (CG), each followed by three Family Health Strategy teams (Figure 1). To avoid interaction between the IG and CG, the groups were divided according to their geographic location. Individuals undergoing weight loss treatment, type I diabetics, and pregnant women were excluded.

All six Family Health Strategy teams were well established, providing similar standard care to their patients. The CG $(n=81)$ received only the standard care, while the IG $(n=198)$ received the standard care and participated in the structured activities of a multidisciplinary program that promotes healthy habits, the program Jogo de Cintura, which includes nutrition and physical activity interventions.

The activities of the said program lasted eight months, from March to November 2009, and consisted of thirteen workshops blending lecture and practice, totaling 38 hours. The subjects were healthy eating ( 5 hours), home vegetable garden ( 5 hours), whole use of fruits and vegetables (5 hours), food labeling (5 hours), experimental cooking (6 hours), psychological support and motivation (7 hours), and physical activity counseling (5 hours). In addition to the workshops, groups were established to perform supervised physical activities, including daily walks and gym class three times a week, each lasting one hour. The logic model of the program with a detailed description of its structure and functioning are described elsewhere ${ }^{8}$.

Anthropometric and biochemical data were collected on three occasions: at baseline, after 4 months, and after 8 months of intervention. At baseline, data were collected from the entire group on the same day, while the subsequent collections were done with 30 to 40 individuals at a time. Community health agents scheduled the examinations, and the data were collected at 


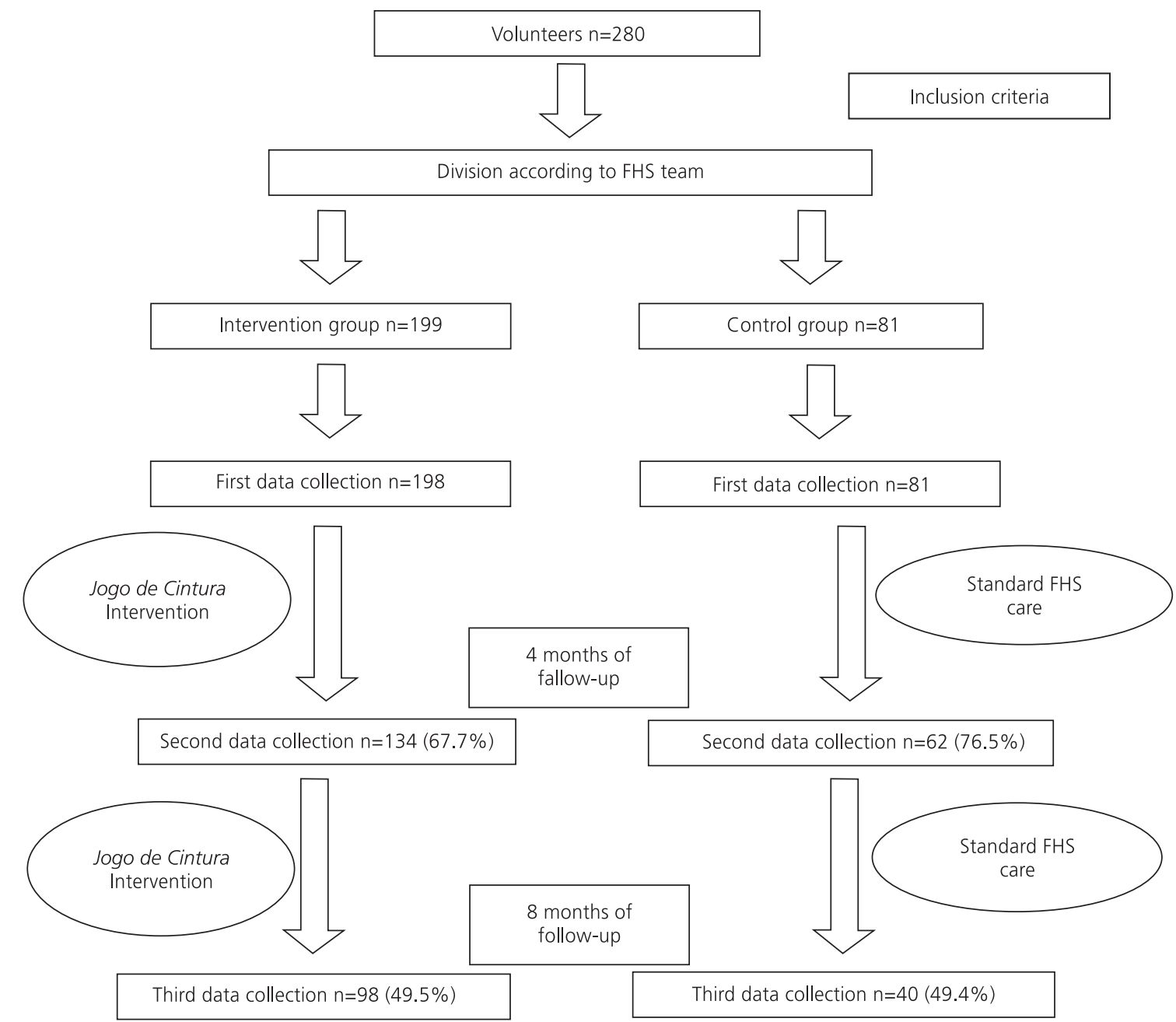

Figure 1. Study design, composition of the intervention group, and respective sample losses during follow-up. São Sebastião (DF), Brazil, 2009.

Note: FHS: Family Health Strategy.

the health facilities home to the Family Health Strategy teams. Body weight and height were measured by a portable digital scale (Tanita ${ }^{\circledR}$ ) and wall-mounted stadiometer (Sanny ${ }^{\circledR}$ ) respectively, with the individuals barefoot, wearing light clothing ${ }^{9}$. WC was measured by an inelastic tape measure $\left(S a n n y^{\circledR}\right)$ at the midpoint between the last rib and the iliac crest $^{9}$. The participants were considered overweight when $25 \mathrm{~kg} / \mathrm{m}^{2} \leq \mathrm{BMI}$ $\leq 29.9 \mathrm{~kg} / \mathrm{m}^{2}$ and obese when $\mathrm{BMI} \geq 30 \mathrm{~kg} / \mathrm{m}^{210}$. Blood samples were collected after a 12-hour fast for the biochemical tests, which included blood glucose, triglycerides, total cholesterol,
Low-Density Lipoprotein Cholesterol (LDL-C), and High-Density Lipoprotein Cholesterol (HDL-C), as recommended by the regional health laboratory of São Sebastião (DF) ${ }^{11}$.

Descriptive and inferential statistical analyses were done by the software SPSS ${ }^{\top M}$ version 17.0. Univariate factorial analysis of variance (Anova) and McNemar's test were used for analyzing the differences between the groups and the intragroup changes during the study period. All analyses were intention-to-treat, including the dropouts who had attended at least one group meeting. Individuals whose blood and 
Table 1. Age, education level, and baseline Body Mass Index (BMI) of adults followed by the Family Health Strategy by intervention group. São Sebastião (DF), Brazil, 2009.

\begin{tabular}{|c|c|c|c|}
\hline & Intervention group ${ }^{1}(n=198)$ & Control group $^{2}(n=81)$ & $p$-value \\
\hline Women (\%) & 95.5 & 87.7 & \multirow{2}{*}{0.033} \\
\hline Men (\%) & 4.5 & 12.3 & \\
\hline \multicolumn{4}{|l|}{ Age (\%) } \\
\hline 18 to 29 years & 10.6 & 13.6 & \multirow{5}{*}{0.088} \\
\hline 30 to 39 years & 29.8 & 44.4 & \\
\hline 40 to 49 years & 31.8 & 22.2 & \\
\hline 50 to 59 years & 19.2 & 16.1 & \\
\hline$\geq 60$ years & 8.6 & 3.7 & \\
\hline \multicolumn{4}{|c|}{ Years of formal education (\%) } \\
\hline 0 to 8 & 69.7 & 67.8 & \multirow{3}{*}{0.838} \\
\hline 9 to 11 & 26.8 & 28.5 & \\
\hline 12 or more & 3.5 & 3.7 & \\
\hline$B M I K g / m^{2}($ mean $\pm S D)$ & $32.5 \pm 4.6$ & $31.95 \pm 5.52$ & 0.671 \\
\hline
\end{tabular}

Note: ${ }^{1}$ Intervention group: received the standard care provided by Family Health Strategy teams and actions provided by the program Jogo de Cintura; ${ }^{2}$ Control group: received the standard care provided by Family Health Strategy teams; SD: Standard Deviation.

anthropometric measurements had been collected only once were considered sample losses, since it prevented intragroup comparisons. The significance level was set at $5 \%$.

The present study was approved by the Research Ethics Committee of the Secretaria de Estado de Saúde - Distrito Federal (SES-DF, State Department of Health of Federal District) under protocol number 229/2008. All participants signed a free and informed consent form before joining the study.

\section{RE S U L T S}

The sample consisted mainly of women $(93.2 \%)$, and $69.1 \%$ of the participants had eight years or less of formal education. The mean age and BMI and respective Standard Deviations (SD) were $42.0 \pm 11.2$ years and $32.1 \pm 5.3 \mathrm{Kg} / \mathrm{m}^{2}$, respectively. The only demographic and anthropometric variables that differed between the IG and CG were gender and BMI (Table 1).

Approximately $50 \%$ of the participants of each group completed the study (Figure 1). The demographic characteristics and nutritional status of completers and dropouts did not differ (data not shown).
Table 2 shows the changes in the anthropometric and biochemical parameters of the two groups during the intervention period. The baseline biochemical results of both groups were within the normal ranges. After four months of intervention, the glucose levels of both groups increased, and between the fourth and eighth months the total cholesterol, LDL-C, and HDL-C decreased significantly. The triglyceride levels of the IG decreased marginally $(p=0.69)$ between the fourth and eighth intervention months.

Factorial Anova, which tested the intraand intergroup differences, showed that the IG body weight decreased significantly when intervention time was controlled ( $p=0.003$ ). The baseline weight of the IG and CG did not differ significantly $(p=0.245)$. The IG lost approximately seven centimeters of WC during the intervention $(p=0.003)$. The weight lost by the IG was enough to change their nutritional status classification according to $\mathrm{BMI}$, but not enough to reach a normal body weight range. The baseline prevalence of obesity $(63.3 \%)$ decreased to $49.4 \%$ at the end of the eight-month intervention period ( $p=0.027$ ) (Figure 2 ). 
Table 2. Mean \pm standard deviation of body weight, Waist Circumference (WC), and biochemical profile during the follow-up of overweight and obese adults followed by the Family Health Strategy by intervention group. São Sebastião (DF), Brazil, 2009.

\begin{tabular}{|c|c|c|c|c|c|c|c|c|c|c|c|c|}
\hline & \multicolumn{6}{|c|}{ Intervention group 1} & \multicolumn{6}{|c|}{ Control group ${ }^{2}$} \\
\hline & \multicolumn{2}{|c|}{$\begin{array}{l}\text { Baseline } \\
(n=198)\end{array}$} & \multicolumn{2}{|c|}{$\begin{array}{l}4 \text { months } \\
(n=134)\end{array}$} & \multicolumn{2}{|c|}{$\begin{array}{c}8 \text { months } \\
(n=98)\end{array}$} & \multicolumn{2}{|c|}{$\begin{array}{c}\text { Baseline } \\
(\mathrm{n}=81)\end{array}$} & \multicolumn{2}{|c|}{$\begin{array}{c}4 \text { months } \\
(\mathrm{n}=62)\end{array}$} & \multicolumn{2}{|c|}{$\begin{array}{c}8 \text { months } \\
(n=40)\end{array}$} \\
\hline & $M$ & SD & $M$ & SD & $M$ & SD & $M$ & SD & $M$ & SD & $M$ & SD \\
\hline Body weight $(\mathrm{Kg})$ & 78.8 & $14.9^{\mathrm{a}}$ & 77.5 & $14.1^{\mathrm{a}}$ & 74.4 & $12.9^{\mathrm{a}}$ & 81.1 & 14.3 & 80.8 & 14.7 & 78.1 & 12.6 \\
\hline$W C(\mathrm{~cm})$ & 102.2 & $11.3^{* a b}$ & 96.4 & $11.4^{\mathrm{a}}$ & 94.8 & $11.8^{\mathbf{b}}$ & 97.3 & $9.9^{*}$ & 97.0 & 13.5 & 96.1 & 10.1 \\
\hline \multicolumn{13}{|l|}{ Biochemical profile } \\
\hline Blood glucose (mg/dL) & 88.6 & $28.9^{* a b}$ & 98.71 & $18.5^{\mathrm{ab}}$ & 93.8 & $23.6^{\mathrm{b}}$ & 96.1 & $28.7^{* a}$ & 102.3 & $19.1^{\mathrm{ab}}$ & 94.6 & $11.1^{\mathrm{b}}$ \\
\hline Triglycerides (mg/dL) & 133.2 & 68.6 & 126.5 & 67.0 & 118.8 & 59.8 & 144 & 67.5 & 145.0 & 74.1 & 164.4 & 94.1 \\
\hline Total cholesterol (mg/dL) & 195.2 & $39.4^{\mathrm{a}}$ & 193.7 & $36.5^{\mathrm{b}}$ & 182.2 & $40.0^{\mathrm{ab}}$ & 199 & $43.7^{\mathrm{a}}$ & 203 & $44.6^{\mathbf{b}}$ & 187 & $40.0^{\mathrm{ab}}$ \\
\hline LDL-c (mg/dL) & 0.118 & $34.02^{\mathrm{a}}$ & 124.9 & $32.0^{\mathrm{ab}}$ & 120.7 & $34.1^{\mathrm{b}}$ & 122.9 & $36.3^{\mathrm{a}}$ & 136.5 & $39.7^{\mathrm{ab}}$ & 121.9 & $38.6^{\mathbf{b}}$ \\
\hline $\mathrm{HDL}-\mathrm{c}(\mathrm{mg} / \mathrm{dL})$ & 049.1 & $8.7^{\mathrm{a}}$ & 40.8 & $8.6^{\mathrm{a}}$ & 34.0 & $6.8^{\mathrm{a}}$ & 47.4 & $9.9^{\mathrm{a}}$ & 37.7 & $7.1^{\mathrm{a}}$ & 30.2 & $6.7^{\mathrm{a}}$ \\
\hline
\end{tabular}

Note: 1Intervention group: received the standard care provided by Family Health Strategy teams and actions provided by the program Jogo de Cintura; ${ }^{2}$ Control group: received the standard care provided by Family Health Strategy teams. ${ }^{\text {a, }}$ same letters indicate significant intragroup differences $(p<0.05)$ according to univariate factorial analysis of variance; * differences between the groups $(p<0.05)$. LDL-c: Low-Density Lipoprotein cholesterol; HDL-c: High-Density Lipoprotein Cholesterol; M: Media; SD: Standard Deviation.

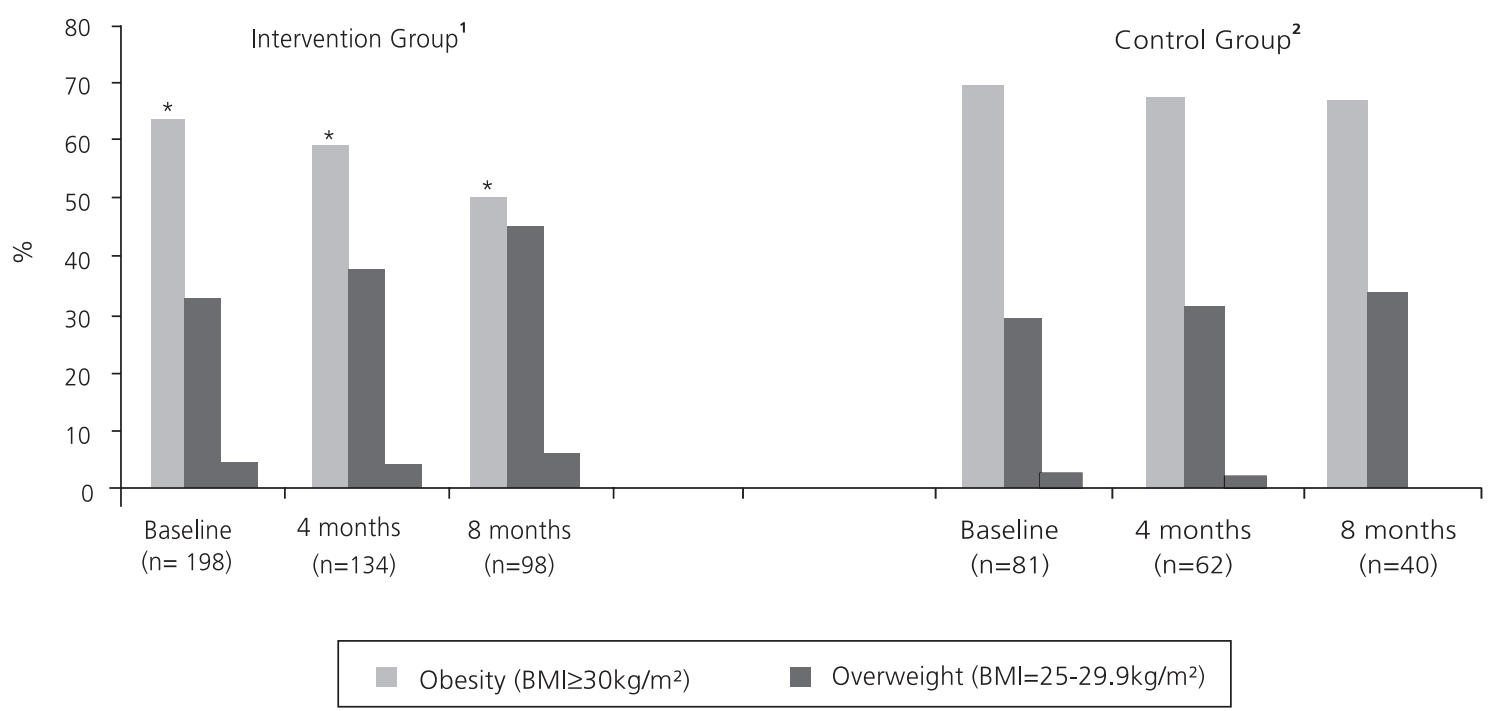

Figure 2. Body Mass Index (BMI) changes during the follow-up of adults followed by the Family Health Strategy by intervention group. São Sebastião (DF), Brazil, 2009.

Note: ${ }^{1}$ Intervention group: received the standard care provided by Family Health Strategy teams and actions provided by the program Jogo de Cintura; ${ }^{2}$ Control group: received the standard care provided by Family Health Strategy teams.

${ }^{*} \Delta$ Significant difference: $p<0.05$ according to McNemar's test.

\section{DISCUSSION}

The present study analyzed the results of a multidisciplinary program that promotes healthy habits in overweight adults covered by Family Health Strategy and compared the results with those of individuals given the standard Family Health Strategy care in a low-income Region of Distrito Federal. This region was chosen because low education level and low income have been associated with NCD risk factors, such as obesity, poor food choices, and sedentary leisure activities ${ }^{12}$. 
Concordant with the expressive increase in NCD morbidity and mortality, the changes in sanitary policies and practices to promote healthy habits (making a healthy diet and physical activity priorities), and the institutionalization of health promotion and better quality of life ${ }^{4}$, the Family Health Strategy is a logistic element in the Brazilian Sistema Único de Saúde (SUS, Unified Health (are System) for promoting and maintaining health, and preventing, treating, and rehabilitating individuals with the most common health problems and diseases. The Family Health Strategy relies on the actions of multidisciplinary teams to ensure full individual and family care, and it is an important initiative for preventing and controlling NCD risk factors through sustainable and integrated actions ${ }^{13}$.

However, the Family Health Strategy is still under development, and the paradigm change in health care continues to be a challenge for SUS managers and professionals. Family Health Strategy professionals have questions and difficulties regarding the development of participative, democratic, and multi-professional management and practices that use highly complex, low-density, and maximally effective technologies integrated with a network of services at different levels of the health system ${ }^{14}$.

Hence, when overweight and obese individuals covered by the Family Health Strategy were followed for eight months, some anthropometric and biochemical parameters of both groups (IG and CG) improved, but when the standard care provided by the Family Health Strategy was combined with a better-structured, multi-professional intervention (IG), its effectiveness increased, as the present study shows.

The study results are important because obesity is frequently associated with changes in the lipid profile and insulin resistance, together known as the metabolic syndrome ${ }^{15-17}$, whose prevalence in adults from the Distrito Federal is $32 \%{ }^{18}$. However, risk may exist even when biochemical parameters are within the normal ranges, such as the means observed in the present sample. Obesity, especially abdominal obesity, is an independent risk factor for cardiovascular diseases ${ }^{17}$. As the NCD, biochemical changes may occur independently, such as euglycemia associated with high insulin. Thus, biochemical parameters need to be monitored and compared with basal levels and reference values to check either their levels or the results of an intervention ${ }^{19}$.

The fasting blood glucose of both groups increased significantly between baseline and the first follow-up four months later, contrary to the anthropometric results, especially of the IG. Normally, excess body fat induces systemic inflammation, leading to insulin resistance and consequently, high blood glucose ${ }^{17}$. As the IG lost weight, the glucose levels were expected to reduce gradually or remain the same, but not to increase. It is possible that the baseline fasting glucose level was relatively low because of the prolonged fasting period that preceded the first blood collection, since blood samples from all participants were collected on the same day. Although the launching event was important to make the community aware of the program, it may have compromised the baseline data. In the follow-ups, blood was collected from small groups at a time, enabling a better control of the fasting period. The decrease in blood glucose seen between the four- and eight-month follow-ups indicates that blood glucose behaved similarly in both groups, evidencing the benefits of the standard care provided by the Family Health Strategy.

The intervention improved some biochemical parameters significantly, namely total cholesterol and LDL-c between the fourth and eighth months. The CG, counseled and monitored by their Family Health Strategy teams, also experienced a significant reduction in both parameters, resulting in no significant difference between the groups during the follow-up period. Behavioral changes may affect metabolism even when they are not accompanied by 
anthropometric changes, as seen in the CG of this and other studies ${ }^{20-22}$. This study shows that the standard care provided by the Family Health Strategy was beneficial.

Both groups experienced a significant reduction in $\mathrm{HDL}-\mathrm{C}$, despite the promotion of physical activity and weight loss, especially in the IG. In addition to the fact that this variable is influenced by other factors not investigated by the present study, such as genetics, diet, and level of physical activity, other studies have shown that a rise in HDL-C is associated with frequent and vigorous physical activity ${ }^{23,24}$. Perhaps the physical activities proposed by the program Jogo de Cintura were not vigorous enough to increase $\mathrm{HDL}-\mathrm{C}$ in the study period.

Improved biochemistry and moderate weight loss (BMI), especially loss of abdominal fat (WC), reduced the cardiovascular risk of obese individuals 22,25 , showing that the treatment goals were achieved. Thus, the result of the proposed intervention program was positive, since the weight lost improved nutritional status, reducing the prevalence of obese individuals at the end of the intervention. The fact that the lower prevalence of obesity did not increase the prevalence of ideal weight but of overweight suggests that, although the weight lost was modest, it was enough to improve nutritional status, reducing cardiovascular risk considerably ${ }^{25}$ regardless of some unimproved biochemical parameters. Similar studies that encouraged the consumption of healthy foods and physical activity also reduced cardiovascular risk $22,26,27$.

However, one of the problems faced by health-promoting programs is that attendance decreases as the intervention period increases, resulting in significant sample losses during the intervention as seen in this and other studies ${ }^{28,29}$. A study conducted in the Distrito Federal provided nutrition education to a group of overweight and obese individuals for three months but only $45.8 \%$ of the sample had excellent attendance ${ }^{28}$. Although the present study was longer, lasting eight months, attendance of the sample was slightly higher, as approximately $50.0 \%$ of the sample completed the study.

Such intervention studies should not only compare dropout and completer profiles but also include intention-to-treat analysis ${ }^{29}$, preventing completers' positive results from being overestimated because of dropouts' possibly negative results. Therefore, this methodological control showed that despite the average attendance, the intervention promoted improvements in the study parameters, especially the anthropometric ones.

In addition to the dropout rate whose effect was partially minimized by the selected statistical treatment, other study limitations include its quasi-experimental design, with unmatched and nonrandomized distribution of the participants into a control and intervention group; the high prevalence of women, which compromises extrapolation to the general population; and the study not assessing changes in lifestyle. Higher female participation in healthpromoting programs is common and possibly due to greater time availability or health concern ${ }^{22}$. New studies should investigate whether the newly acquired healthy habits and study results will be long lasting and the factors that contribute to their sustainability.

The study results may encourage the inclusion of contextualized, multi-professional, health-promoting actions in the Family Health Strategy since they are inexpensive, simple, and more effective in reducing obesity and NCD risk. The expansion of health-promoting initiatives, such as the Programa Academia da Saúde (Health Gym Program) ${ }^{30}$ launched recently, may be facilitated if the existing programs have already been systematized and evaluated ${ }^{31}$. Another advantage of promoting health system initiatives is the ease of conducting periodic assessments. Other studies are needed to clarify the factors that promote attendance (or abandonment) in programs that promote healthy practices to reduce NCD risk and morbidity. 


\section{CONCLUSION}

The multidisciplinary intervention program together with the standard care provided by the Family Health Strategy effectively reduced NCD risk factors, especially anthropometric parameters. The Family Health Strategy team should continuously and dynamically incorporate the surveillance and health promotion actions developed by this intervention program, since they can be adjusted to different realities and assessed for sustainability.

\section{ACKNOWLEDGMENTS}

We thank the Gerência de Doenças e Agravos não Transmissiveis from the Secretaria de Saúde do Distrito Federal (GDANT/SES-DF) members Édisa B. Lopes, Lígia T. M. de Azevedo, Sarah G. G. Tinoco and Simony P. A. F. Leite for the support they gave to the study and Felipe Valentini for helping with data analysis.

\section{CONTRIBUTORS}

C ROMEIRO, JAD NOGUEIRA, ES DUTRA and KMB CARVALHO Responsible for conceiving and designing the study, analyzing and interpreting the results, and writing and reviewing the article.

\section{REFERENCES}

1. Schmidt MI, Duncan BB, Silva GA, Menezes AM, Monteiro CA, Barreto SM, et al. Chronic noncommunicable diseases in Brazil: Burden and current challenges. Lancet 2011; 377(9781):1949-61. doi: 10.1016/S0140-6736(11)60135-9.

2. Brasil. Ministério da Saúde. Vigitel Brasil 2011: vigilância de fatores de risco e proteção para doenças crônicas por inquérito telefônico. Brasília: Ministério da Saúde; 2012.

3. Yokota RTC, Vasconcelos TF, Ito MK, Dutra ES, Baiocchi KC, Merchán-Hamann E, et al. Prevalência de fatores de risco para doenças crônicas não transmissíveis em duas regiões do Distrito Federal. Com Ciênc Saúde. 2007; 18(4):289-96.

4. Brasil. Ministério da Saúde. Política nacional de promoção da saúde. Brasília: Ministério da Saúde; 2007.
5. Brasil. Distrito Federal. Secretaria de Estado de Saúde. Gerência de doenças e agravos não transmissíveis. plano distrital de promoção da saúde. Brasília: Secretaria de Estado de Saúde; 2007.

6. Tinoco SGG, Leite EG, Baldini NLF. Reflexões sobre a política de promoção da saúde no Distrito Federal e sua integração com a Estratégia Saúde da Família. Tempus - Actas Saúde Colet. 2009; 3(2):64-75.

7. Brasil. Distrito Federal. Índice de desenvolvimento humano por região administrativa: Distrito Federal - 2000. Brasília: Governo do Distrito Federal [acesso 2011 maio 7]. Disponível em <http://www. distritofederal.df.gov.br/005/00502001.asp? ttCD_CHAVE $=1621>$.

8. Romeiro C, Nogueira JAD, Tinoco SG, Carvalho KMB. O modelo lógico como ferramenta de planejamento, implantação e avaliação do programa de promoção da saúde na estratégia de saúde da família do Distrito Federal. Rev Bras Ativ Fís Saúde. 2013; 18(1):132-42. doi: 10.12820/2317-16 34.201.

9. Gibson RS. Anthropometric assessment of body composition. In: RS Gibson editores. Principles of nutritional assessment. New York: Oxford Univesity Press; 1990. pp.187-207.

10. World Health Organization. Diet, nutrition and prevention of chronic diseases. Technical Report Series, 916. Geneva: WHO; 2003.

11. Brasil. Ministério da Saúde. Normas e manuais técnicos: Série A. Brasília: Ministério da Saúde; 2003.

12. Monteiro CA, Conde WL, Castro IR. The changing relationship between education and risk of obesity in Brazil (1975-1997). Cad Saúde Pública. 2003; 19 (Supl 1):67-75.

13. Paim JS, Travassos C, Almeida C, Bahia L, Macinko J. The Brazilian health system: history, advances, and chalenges. Lancet. 2011; 377(9779):1778-97. doi: 10.1016/S0140-6736(11)60054-8.

14. Brasil. Ministério da Saúde. Saúde da família: uma estratégia para a reorientação do modelo assistencial. Brasília: Ministério da Saúde; 1997.

15. Alberti K, Eckel R, Grundy S, Zimmet P, Cleeman J, Donato $\mathrm{K}$, et al. Harmonizing the metabolic syndrome: A joint interim statement of the International Diabetes Federation Task Force on Epidemiology and Prevention; National Heart, Lung, and Blood Institute; American Heart Association; World Heart Federation; International Atherosclerosis Society; and International Association for the Study of Obesity. Circulation. 2009; 120(16):1640-45.

16. Hubert HB, Feinleib M, McNamara PM, Castelli WP. Obesity as an independent risk factor for cardiovascular disease: A 26-year follow-up of 
participants in the Framingham Heart Study. Circulation. 1983; 67(5):968-77.

17. Antuna-Puente B, Feve B, Fellani S, Bastard J-P. Adipokines: The missing link between insulin resistance and obesity. Diabetes Metab. 2008; 34(1):2-11.

18. Dutra ES, Carvalho KMB, Miyazaki E, MerchánHamann E, Ito MK. Metabolic syndrome in central Brazil: Prevalence and correlates in the adult population. Diabetol Metab Syndrome. 2012; 4(1):20-9.

19. Esposito K, Pontillo A, Di Palo C, Giugliano G, Masella M, Marfella R, et al. Effect of weight loss and lifestyle changes on vascular inflammatory markers in obese women. JAMA. 2003; 289(14): 1799-1804.

20. Look AHEAD Research Group. Reduction in weight and cardiovascular disease risk factors in individuals with type 2 diabetes: one-year results of the look AHEAD trial. Diabetes Care. 2007; 30(6):1374-83.

21. Monteiro RCA, Riether PTA, Burini RC. Efeito de um programa misto de intervenção nutricional e exercício físico sobre a composição corporal e os hábitos alimentares de mulheres obesas em climatério. Rev Nutr. 2004; 17(4):479-89. doi: 10.1590/s14 15-5273200400008.

22. Venturim LMVP, Cade NV. Efeitos do programa "P.E.S.O." (Promoção de estilo de vida saudável na obesidade) sobre variáveis antropométricas, hemodinâmicas e bioquímicas. Rev Bras Ativ Fís Saúde. 2007; 12(1):19-26.

23. Wen PC, Wai JPM, Tsai MK, Yang YC, Cheng TYD, Lee $M C$, et al. Minimum amount of physical activity for reduced mortality and extended life expectancy: A prospective cohort study. Lancet. 2011; 378(9798):1244-53. doi: 10.1016/S0140-673 6(11)60749-6.

24. Gomes MA, Duarte MFS. Efetividade de uma intervenção de atividade física em adultos atendidos pela estratégia saúde da família: programa ação e saúde
Floripa - Brasil. Rev Bras Ativ Fís Saúde. 2008; 13(1):44-56.

25. Costa PRF, Assis AMO, Silva MCM, Dias JC, Pinheiro SMC, et al. Mudança nos parâmetros antropométricos: a influência de um programa de intervenção nutricional e exercício físico em mulheres adultas. Cad Saúde Pública. 2009; 25(8):1763-73.

26. Alvarez TS, Zanella MT. Impacto de dois programas de educação nutricional sobre o risco cardiovascular em pacientes hipertensos e com excesso de peso. Rev Nutr. 2009; 22(1):71-9. doi: 10.1590/s1415-52 730009000100007.

27. Simões EJ, Hallal P, Pratt $M$, Ramos $L$, Munk $M$, Damascena W, et al. Effects of a community-based, professionally supervised intervention on physical activity levels among residents of Recife, Brazil. Am J Public Health. 2009; 99(1):68-75.

28. Guimarães NG, Dutra ES, Ito MK, Carvalho KMB. Adesão a um programa de aconselhamento nutricional para adultos com excesso de peso e comorbidades. Rev Nutr. 2010; 23(3):323-33. doi: 10.1590/s1415-52732010000300001.

29. Sichieri R, Moura AS, Genelhu V, Hu F, Willet WC. An 18-mo randomized trial of a low- glycemic index diet and weight change in Brazilian women. Am J Clin Nutr. 2007; 86(3):707-13.

30. Brasil. Ministério da Saúde. Portaria n 719 de 07 de abril de 2011. Institui o Programa Academia da Saúde no âmbito do Sistema Único de Saúde. [acesso 2012 jan 16]. Disponível em: <http:// portal.saude.gov.br/portal/arquivos/pdf/portaria_ academia_saude_719.pdf>.

31. United States. Department of Health and Human Services. Physical activity evaluation handbook. Atlanta: Department of Health and Human Services; 2002. 